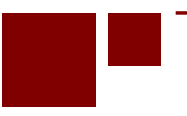

C E N T E R for RETIREMENT RES E A R C H at BOSTON COLLEGE

\title{
EVALUATING THE IMPACT OF SOCIAL SECURITY BENEFITS ON HEALTH OUTCOMES AMONG THE ELDERLY
}

\author{
Padmaja Ayyagari
}

CRR WP 2015-25

September 2015

\author{
Center for Retirement Research at Boston College \\ Hovey House \\ 140 Commonwealth Ave \\ Chestnut Hill, MA 02467 \\ Tel: 617-552-1762 Fax: 617-552-0191 \\ http://crr.bc.edu
}

\begin{abstract}
Padmaja Ayyagari is an assistant professor in the department of health management and policy at the University of Iowa. The research reported herein was performed pursuant to a grant from the U.S. Social Security Administration (SSA) funded as part of the Retirement Research Consortium. The opinions and conclusions expressed are solely those of the author and do not represent the opinions or policy of SSA, any agency of the federal government, the University of Iowa, or Boston College. Neither the United States Government nor any agency thereof, nor any of their employees, makes any warranty, express or implied, or assumes any legal liability or responsibility for the accuracy, completeness, or usefulness of the contents of this report. Reference herein to any specific commercial product, process or service by trade name, trademark, manufacturer, or otherwise does not necessarily constitute or imply endorsement, recommendation or favoring by the United States Government or any agency thereof.
\end{abstract}

(C) 2015, Padmaja Ayyagari. All rights reserved. Short sections of text, not to exceed two paragraphs, may be quoted without explicit permission provided that full credit, including (C) notice, is given to the source. 


\section{About the Steven H. Sandell Grant Program}

This paper received funding from the Steven H. Sandell Grant Program for Junior Scholars in Retirement Research. Established in 1999, the Sandell program's purpose is to promote research on retirement issues by scholars in a wide variety of disciplines, including actuarial science, demography, economics, finance, gerontology, political science, psychology, public administration, public policy, sociology, social work, and statistics. The program is funded through a grant from the Social Security Administration (SSA). For more information on the Sandell program, please visit our website at: http://crr.bc.edu/?p=9570, send e-mail to crr@bc.edu, or call (617) 552-1762.

\section{About the Center for Retirement Research}

The Center for Retirement Research at Boston College, part of a consortium that includes parallel centers at the University of Michigan and the National Bureau of Economic Research, was established in 1998 through a grant from the Social Security Administration. The Center's mission is to produce first-class research and forge a strong link between the academic community and decision-makers in the public and private sectors around an issue of critical importance to the nation's future. To achieve this mission, the Center sponsors a wide variety of research projects, transmits new findings to a broad audience, trains new scholars, and broadens access to valuable data sources.

Center for Retirement Research at Boston College

Hovey House

140 Commonwealth Ave

Chestnut Hill, MA 02467

Tel: 617-552-1762 Fax: 617-552-0191

http://crr.bc.edu

Affiliated Institutions:

The Brookings Institution

Massachusetts Institute of Technology

Syracuse University

Urban Institute 


\begin{abstract}
Given concerns about the depletion of the Social Security Trust Fund, policymakers are considering several proposals to improve the financial sustainability of the program, including some that would lower benefits over time. The extent to which reductions in Social Security benefits impact individual health and well-being is not well understood. Using data from a nationally representative survey of older adults, we examine the impact of changes in Social Security income on a broad range of elderly health outcomes, including cognitive function, depression, disability and self-rated health. Prior literature has documented a positive association between income and health. However, this association may reflect unmeasured confounders that are correlated with both income and health (e.g. childhood environment) or may reflect the impact of health on income. To address these concerns and to identify the causal impact of income on health, we employ an instrumental variables strategy based on changes in Social Security income due to amendments to the Social Security Act in the 1970s. We discuss the implications of our findings for aging populations and for public policy.
\end{abstract}

The paper finds that:

- Higher Social Security benefits due to amendments to the Social Security Act in the 1970s led to significant improvements in elderly health outcomes. Specifically, individuals receiving higher Social Security benefits due to these amendments saw significant improvements in functional limitations (e.g. bathing, eating, preparing meals) and cognitive function.

- Improvements in health are not uniform across all groups. In particular, improvements in cognitive function were larger for individuals with better cognition.

- Further, higher Social Security income led to significant decreases in depressive symptoms but only in the case of households whose primary Social Security beneficiary had less than a high school education.

The policy implications of the findings are:

- Our findings have important implications for aging populations and for public policy. Our findings suggest that cuts to Social Security benefits could potentially have 
significant negative impacts on the functional limitations and cognitive function of older adults, while increases in benefits could lead to improvements in health outcomes.

- In addition to the direct impact on population health, increases in Social Security benefits could potentially be offset by reduced health care expenditures by the Medicaid or Medicare program, since functional limitations and cognitive impairments are often associated with significant health care spending. 


\section{Executive Summary}

As U.S. policymakers consider various proposals to address the financial sustainability of the Social Security program, it is important to evaluate the extent to which reductions in Social Security benefits may impact individual health and well-being. Although a positive association between income and health has been documented by prior literature, the extent to which this association represents causal effects is not well understood. In this study, we use a quasiexperimental approach to evaluate the impact of Social Security income on a wide range of health outcomes, including cognitive function, depression, disability and self-rated health.

Income may affect health through several pathways. Higher income reduces financial strain, resulting in lower stress and fewer depressive symptoms, which have also been linked to cognitive decline. Individuals with higher incomes have better access to health care, which may help delay the onset of severe health conditions or better manage current chronic conditions. Higher Social Security income has been shown to increase the likelihood of early retirement, and there is strong evidence that early retirement leads to faster declines in cognition. On the other hand, retirement has also been shown to improve psychological well-being. Further, unmeasured confounders (e.g. childhood environment, school quality) may influence both income and health, or causality may run from health to income, leading to a spurious correlation between the two. Therefore, the net impact of Social Security income on health outcomes is an empirical question.

To identify the causal impact of Social Security benefits, we examine changes in Social Security income due to amendments to the Social Security Act in 1972 and 1977, commonly referred to as the "Social Security Notch.” Prior to 1972, Social Security payments were not indexed for inflation and benefits instead had been periodically increased by Congress. In 1972, the Social Security Act was amended to provide an annual automatic cost-of-living adjustment for benefits. However, the formula used to index benefits was flawed, leading to a faster increase in benefits relative to inflation (referred to as "double indexation”). To correct this error, the Social Security Act was amended in 1977, leading to a reduction in benefits for those born in 1917 or later. These changes resulted in higher benefit amounts for individuals born during 1915 to 1917, compared to adjacent cohorts with the same work history. Thus, by comparing the health outcomes of persons born during 1915 to 1917 to the health of adjacent cohorts, we are able to identify estimates of the relationship between income and health based on quasi-experimental evidence. 
We use data from the Study of Assets and Health Dynamics among the Oldest Old (AHEAD), a longitudinal survey of community dwelling older adults and their spouses. We restrict our sample to households born between 1901 and 1930 and employ an instrumental variables regression model to identify the causal impact of Social Security benefits on health. The instrument is a binary indicator for being born during 1915 to 1917, and the key explanatory variable is self-reported Social Security income at the household level. Social Security income is, on average, about \$420 higher for the 1915-1917 cohort compared to the other cohorts. Dependent variables include four measures of cognitive function: serial 7, which measures working memory; word recall, which measures episodic memory; mental status, which measures knowledge, language, and orientation; and the total cognition score, which sums the mental status and word recall scores. We also estimate regressions using the count of Activities of Daily Living (ADL) and Instrumental Activities of Daily Living (IADL) limitations as dependent variables. Depression is measured using an abridged 8-item version of the Center for Epidemiologic Studies (CESD) scale that asks respondents how they felt for much of the time over the past week (e.g. depressed, lonely). Self-rated health is based on a survey question asking individuals to rate their health as excellent, very good, good, fair or poor. Regressions also include a basic set of sociodemographic characteristics (e.g. age, gender, race and ethnicity, geographic region of residence, and marital status).

We find that higher Social Security benefits due to the 1977 amendments led to significant improvements in cognitive function and reductions in ADL and IADL limitations. Specifically, a \$1,000 increase in annual Social Security income increases the total cognitive score by approximately 4 percent and decreases ADL and IADL limitations by approximately 16 percent. In addition, we find that the number of depressive symptoms decreases by about 19 percent for households whose primary Social Security beneficiary has less than a high school education, but there is no significant change in the mental health of households whose primary beneficiary has a high school degree or higher education. Further, we use instrumental variable quantile regression models to assess differences in the impact of income at different quantiles of the distribution of total cognition. We find that the effect of income is larger at higher quantiles, suggesting that individuals with better cognitive function experience larger gains. Our findings suggest that changes to Social Security benefits have important implications for the health and well-being of the elderly. Reductions to benefits could potentially have significant negative 
impacts on the functional limitations and cognitive function of older adults, while increases in benefits could lead to improvements in health outcomes. In addition to the direct impact on population health, changes in Social Security benefits could potentially be offset by reduced health care expenditures by the Medicaid or Medicare program, since functional limitations and cognitive impairments are often associated with significant health care spending. 


\section{Introduction}

The U.S. Social Security program is expected to face substantial financial challenges in the near future due to demographic changes, including population aging due to the baby boom generation, increasing life expectancy, and a declining worker-to-beneficiary ratio. Proposals to address concerns about the financial sustainability of the Social Security program include reducing benefits to future recipients. For example, a potential change to the Social Security program is to index benefits using the chained Consumer Price Index, which would result in lower annual increases for recipients. Other changes would increase benefits for certain targeted groups. For example, another potential change is to increase the minimum Social Security benefits for low-wage workers (Springstead, Whitman, and Shoffner 2014). The extent to which such changes in Social Security benefits affect individual health and well-being is not well understood. Existing studies have not reached a consensus on the impact of Social Security benefits on health; decreases in benefits due to amendments to the Social Security Act in 1977 significantly reduced prescription drug use (Moran and Simon 2006) and mortality rates (Snyder and Evans 2006), but did not have any impact on weight (Cawley, Moran, and Simon 2010). More generally, there is not a consensus on the impact of income, including retirement income, on health outcomes (Smith 1999). In this study, we contribute to this literature and the understanding of the potential influences of changes to Social Security benefits by evaluating the impact of Social Security income on a broad set of health outcomes among the elderly, including cognitive function, depression, disability, and self-rated health.

In addition to affecting individual well-being, the health outcomes we focus on are associated with substantial health care expenditures and impose a significant financial burden on public programs such as Medicare and Medicaid (Ayyagari, Salm, and Sloan 2007, Unützer et al. 2009, Hurd et al. 2013). Declines in self-rated health and in cognition often precede the onset of more severe health conditions such as Alzheimer's disease (AD) or other dementias, which can seriously impair an individual's ability to carry out even basic daily activities. Aggregate health care payments for persons with AD, estimated to be $\$ 200$ billion in 2012, are expected to grow over the next few years due to the aging of the baby boom generation (Alzheimer's Association 2012). Depression is strongly associated with low income and is often more severe among persons with disability. 
Social Security income could affect health outcomes among the elderly through several pathways. Greater income could improve health through less financial strain, better access to health care, and more beneficial living arrangements. Higher income reduces financial strain, resulting in lower stress and fewer depressive symptoms, which in turn slows age-related cognitive decline (Mendes De Leon, Rapp, and Kasl 1994). Individuals with greater income have greater access to health care, which may help delay the onset of severe health conditions or better manage current chronic conditions. Even among Medicare beneficiaries, income is correlated with more coverage through the purchase of supplemental Medigap coverage (Ettner 1997, Fang, Keane, and Silverman 2008). Social Security income has also been shown to affect the likelihood of living with others for elderly widows and divorcees (Engelhardt, Gruber, and Perry 2005). Some studies have found that living alone is detrimental to neurocognitive health and is associated with more depressive symptoms (Daviglus et al. 2010). Higher income, in particular higher Social Security income, has been found to reduce labor supply and lead to early retirement (French 2005, van der Klaauw and Wolpin 2008). Previous research has documented that reductions in Social Security benefit levels have led to increases in labor force participation for persons older than 65 years (Snyder and Evans 2006). There is strong evidence that being engaged in work is protective of cognitive impairment and that early retirement leads to faster declines in cognition (Rohwedder and Willis 2010, Bonsang, Adam, and Perelman 2012, Mazzonna and Peracchi 2012). Therefore, early retirement or reduced work may offset the other beneficial pathways through which higher income affects cognition. However, the impact of retirement is not uniform across all health outcomes. In particular, prior work has found that retirement improves psychological well-being (Charles 2004). Therefore, the net relationship between income and health outcomes is theoretically ambiguous. Further, any observed association between income and health may represent a spurious correlation due to unmeasured confounders that are correlated with both income and elderly health outcomes, such as childhood environment (Almond and Currie 2011).

This project examines the relationship between Social Security income and the health of elderly individuals by using a quasi-experimental approach to identify the causal impact of income on cognitive function, disability, depression and self-rated health. Specifically, we assess the impact of exogenous changes to Social Security benefits due to amendments to the Social Security Act in 1972 and 1977, commonly referred to as the "Social Security Notch," 
These amendments resulted in adjacent cohorts receiving different benefits for the same work history. Using data from the Study of Assets and Health Dynamics among the Oldest Old (AHEAD), we find that higher Social Security income improves cognitive function, disability and mental health but has no impact on self-rated health.

\section{Background on the Social Security Notch}

The Social Security notch has been described in detail by prior studies (Krueger and Pischke 1992, Engelhardt, Gruber, and Perry 2005) and on the website of the Social Security Administration. ${ }^{1}$ Here we provide a brief overview of the notch changes that are relevant to our study. Prior to 1972, Social Security payments were not indexed for inflation and benefits instead had been periodically increased by Congress. In 1972, the Social Security Act was amended to provide an annual automatic cost-of-living adjustment for benefits. However, the formula used to index benefits was flawed, leading to a faster increase in benefits relative to inflation (referred to as "double indexation”), so that workers born after 1910 received an unintended windfall gain. This error was corrected by Congress in 1977, leading to a reduction in benefits for those born in 1917 or later. To avoid abrupt changes for those close to retirement, a five-year transition period was implemented during which benefits were gradually reduced based on a special transition formula. For persons born in 1922 or later, benefits are calculated using the new formula implemented in 1977. These changes resulted in different cohorts receiving different benefits for the same work history. Moreover, due to grandfathering provisions, these policy changes resulted in permanent changes in the Social Security benefits received by these cohorts. The amendments directly affect individuals' incomes but do not impact health or other confounding factors directly. Therefore, by comparing the health outcomes of persons in nearby cohorts with differing Social Security income due to the 1977 amendments, we are able to address key limitations of extant literature and provide estimates of the relationship between income and health based on quasi-experimental evidence.

\footnotetext{
${ }^{1}$ For example, see: http://www.ssa.gov/history/notchfile1.html, http://www.ssa.gov/history/notchfile2.html and http://www.ssa.gov/history/notchfile3.html.
} 


\section{Data}

We use data from the AHEAD longitudinal survey of community-dwelling persons born before 1924 and their spouses, regardless of age. Respondents were first interviewed in 1993 and then re-interviewed in 1995. We use data only from the 1993 wave of the AHEAD to avoid any concerns about attrition between waves.

The dependent variables include a wide range of health measures. The AHEAD includes detailed measures designed to capture various dimensions of cognition: knowledge, reasoning, orientation, calculation, and language. Specifically, we use the following four measures of cognitive function: ${ }^{2}$ (1) serial 7, (2) word recall, (3) mental status, and (4) total cognition score. The AHEAD measures were derived from well-validated scales such as the Mini-Mental State Examination and the Telephone Interview for Cognitive Status and were adapted so that they could be administered in a large population study (Herzog and Wallace 1997). They have been shown to have satisfactory psychometric properties and construct validity (Herzog and Wallace 1997).

Serial 7 measures working memory based on a task in which respondents are asked to subtract 7 from 100 and to continue subtracting 7 from each subsequent number for a total of five times. The score, ranging from 0 to 5 , is the count of correct subtractions across the five trials, with each subtraction being assessed independently. Word recall, a measure of episodic memory, is based on a list of 10 nouns read to the respondent who is then asked to recall as many words as possible in any order (immediate word recall). After approximately 5 minutes, during which time respondents are asked other survey questions, they are asked to repeat the task (delayed word recall). The score, which is the number of words that were correctly recalled from both times, ranges from 0 to 20. Mental status is based on various tests designed to measure knowledge, language and orientation, and sums the scores for serial 7, backwards counting from 20, object naming, date naming and president/vice-president naming. Respondents are asked to count backwards as quickly as possible beginning with the number 20. Answers are coded 0 for incorrect, 1 for correct on the second try and 2 for correct on the first try. In addition, respondents are asked to report the month, day, year and day of the week during their interview, and to name the object they would "usually use to cut paper" and "the kind of prickly plant that

\footnotetext{
${ }^{2}$ In analysis not shown, we also examined two subjective measures of cognition: self-rated current memory (excellent, very good, good, fair or poor) and a self-report of how current memory compares to memory two years back (better, same or worse). We found no impact of Social Security income on either measure of cognition.
} 
grows in the desert.” Each answer is coded 1 for a correct response and 0 for an incorrect one. New-interviewees and re-interviewees ages 65 years or older are also asked to name the current President and Vice President of the United States. Answers are coded 1 for getting each last name right and 0 otherwise. The mental status score ranges from 0 to 15 , with a higher value representing better cognition. Total Cognition Score sums the mental status and word recall scores, and imputes values for missing observations (Fisher et al. 2012, Ofstedal, Fisher, and Herzog 2005). This measure ranges from 0 to 35, with a higher value representing better cognition.

In addition to cognitive function, we assess the impact of income on self-rated health, disability and depression. ${ }^{3}$ Self-Rated Health is based on a survey question asking respondents to rate their health as excellent, very good, good, fair or poor health. We estimate separate models using the continuous measure (ranging from 1 for excellent to 5 for poor health) and a binary indicator for fair or poor health. Disability is measured using the count of limitations performing ADL) and IADL. For ADLs, the survey asks about difficulty walking across a room, dressing, bathing, eating, getting in and out of bed, and using the toilet. For IADLS, the survey asks about difficulty using the phone, taking medication, managing money, and shopping for groceries or preparing meals. Depression is measured using an abridged 8-item version of the Center for Epidemiologic Studies (CESD) scale. Respondents are asked how often they felt depressed, that everything was an effort, whether sleep was restless, felt they could not get going, felt lonely, enjoyed life, felt sad and were happy. In addition to the continuous CESD score, we also use a binary indicator for clinical depression based on a threshold of three or more depressive symptoms. This threshold has been used by prior studies to evaluate clinically relevant depressive symptomatology (Ayyagari and Shane 2015, McInerney, Mellor, and Nicholas 2013).

The key explanatory variable is self-reported household income from Social Security retirement, spousal or widow benefits. All regressions include a basic set of covariates - own age and gender, the primary beneficiary’s age, race and ethnicity, census region of residence, a binary indicator for residing in an metropolitan statistical area and indicators for the type of

\footnotetext{
${ }^{3}$ We also examined two measures of cardiovascular health for a subsample of individuals who reported that they had ever been diagnosed with heart conditions. These measures were self-reports of a heart attack over the past five years and recent experiences of angina or chest pains. Unfortunately, for both measures the sample size was too small (approximately 2000 observations) to yield reliable estimates.
} 
household: male head-married, male head-single, female head-never married, female headwidowed (female head-divorced forms the reference category).

We follow previous studies on the Social Security benefits notch (Krueger and Pischke 1992, Moran and Simon 2006, Cawley, Moran, and Simon 2010, Goda, Golberstein, and Grabowski 2011) in constructing the analysis sample. The analysis is restricted to households in which the primary beneficiary was born between 1901 and 1930. In the case of two-person or male-only households, the male member is designated as the primary beneficiary. In the case of never-married females, the female is designated as the primary beneficiary. In the case of divorced or widowed females, the deceased or former husband is designated as the primary beneficiary. Since year of birth is not available for deceased or former husbands, we subtract three years from the female's year of birth to compute the primary beneficiary's year of birth. Engelhardt, Gruber and Perry (2005) has shown that the median age difference between spouses in this cohort was three years. In addition to the birth-year restrictions, we exclude households that report a Social Security income of less than $\$ 100$ per month and observations with missing or incomplete data.

Figure 1 presents the histograms for each measure of cognition. There is considerable variation in each measure of cognition. In the case of serial 7, about 34 percent of the sample obtains a perfect score while about 8 percent gets every answer wrong. The distribution of the word recall score is slightly right skewed. The majority of individuals (76 percent) get less than or equal to half the answers correct. About 23 percent of the sample obtains a perfect score on the mental status measure. The distribution of the total cognition score is slightly left skewed, with about 30 percent of the sample obtaining a score of 17 or lower. Figure 2 presents the histograms for the physical and mental health measures. About 65 percent of sample persons report excellent to good health. Over 80 percent of individuals report no functional limitations and approximately 40 percent of individuals do not report any depressive symptoms. Table 1 presents summary statistics for the full sample and separately for the cohorts used to create the instrumental variable (described below). The average annual Social Security income for the sample is nearly $\$ 11,000$, which is about 39 percent of total household income, and the average age of the primary Social Security beneficiary is nearly 78 years old. Social Security income is, on average, about $\$ 420$ higher for the 1915-1917 cohort compared to the other cohorts. This 
cohort difference in benefits is about $\$ 1,020$ for households whose primary beneficiary has less than a high school education (not shown).

\section{Methods}

We first estimate the association between Social Security income and each measure of health separately using ordinary least squares (OLS):

$$
\text { Health }_{i h}=\alpha_{1}+\alpha_{2} \text { SSIncome }_{h}+\alpha_{3} X_{i h}+\varepsilon_{i h}
$$

where Health $h_{i}$ represents a measure of health as previously described for individual $i$ in household $h$. The key explanatory variable in equation 1 is Social Security income at the household level ('SSIncome') and $X$ denotes the covariates.

As mentioned above, a key concern with evaluating the relationship between income and health is that unobserved factors may be correlated with both Social Security income and health outcomes leading to a spurious correlation between the two variables. Further, causality may run in the reverse direction with health influencing income, although this is less likely in the case of Social Security income. Thus, the estimate $\alpha_{2}$ from Equation (1) does not identify the causal impact of Social Security income. To address the endogeneity of income, we estimate an instrumental variable (IV) model using the following specification:

$$
\begin{aligned}
& \text { SSIncome }_{h}=\beta_{1}+\beta_{2} \text { Notch }_{h}+\beta_{3} X_{i h}+v_{i h} \\
& \text { Health }_{i h}=\gamma_{1}+\gamma_{2} \text { SSIncome }_{h}+\gamma_{3} X_{i h}+\epsilon_{i h}
\end{aligned}
$$

The IV $\left(\right.$ Notch $\left._{h}\right)$ is a binary indicator that takes the value one for households whose primary beneficiary was born during 1915-1917 and zero for households whose primary beneficiary was born in any other year between 1901 and 1930. The IV model represented by equations (2) and (3) identifies the causal impact of income on health under two key assumptions. The first assumption is that the instrument $\left(\right.$ Notch $\left._{h}\right)$ is a strong predictor of income. Prior studies have documented that the birth years 1915-1917 represent the peak of the benefits notch and the largest deviation of Social Security income from the trend throughout the period 1901-1930. Therefore, a binary variable defining the 1915-1917 cohorts provides the 
strongest instrument and enables the interpretation of the impact of an increase in Social Security income (Goda, Golberstein, and Grabowski 2011, Cawley, Moran, and Simon 2010, Moran and Simon 2006). We can also assess the strength of the instrument in our sample based on the Fstatistic of the weak instrument test (Staiger and Stock 1997, Stock and Yogo 2005). The second key assumption is that the instrument should not be correlated with health except via its effect on income (exclusion restriction). Although this assumption is typically not testable, in the case of our application, it is plausible that being born during 1915 to 1917 should not be correlated with health relative to other adjacent cohorts except due to the differences in Social Security benefits due to the 1977 amendments. All regressions cluster the standard errors at the year of birth level, to account for correlations in health outcomes within birth cohorts.

In addition to estimating the overall impact of Social Security benefits on health, we examine the extent to which these effects vary by educational attainment. ${ }^{4}$ Further, to examine the heterogeneity of the impact of income by level of health, we estimate instrumental variable quantile regression (Chernozhukov and Hansen 2008) where equations 2 and 3 are modified to estimate the impact of income at various quantiles of the distribution of health. Specifically, we focus on the $0.10,0.25,0.5,0.75$, and 0.90 quantiles. Because this methodology is most appropriate for continuous variables, we restrict these analyses to the total cognition score. ${ }^{5}$ Quantile regression allows us to estimate the impact of income not only at the center but also at the tails of the distribution of cognition, thereby providing information on the extent to which changes in Social Security benefits could potentially influence disparities in cognition.

\section{Results}

We begin by examining the correlation between Social Security income and cognitive function using the OLS models (Table 2). Across all four measures of cognition, there is a positive, significant correlation between income and cognition, although the magnitudes of the point estimates are rather modest. Specifically, a \$1,000 increase in annual income is associated with a 0.05 higher serial 7 score, 0.1 higher word recall and mental status score, and a 0.2 higher total cognition score. Relative to the sample means, these estimates represent a 1.4 percent

\footnotetext{
${ }^{4}$ We also explored heterogeneous effects by race and ethnicity, but sample sizes were too small to obtain reliable estimates.

${ }^{5}$ We also explored instrumental variable quantile regressions for some of the other continuous measures of health, including word recall, mental status, and CESD. However, these models did not converge.
} 
increase in the serial 7 score, a 1.2 percent increase in word recall, a 0.8 percent increase in mental status, and a 0.9 percent increase in the total cognition score. Next, we assess the correlation between income and self-rated health, ADLs, IADLs and the CESD score (Table 3). For each of these measures, a higher value indicates worse health. We find that higher income is significantly associated with better self-rated health, fewer ADL and IADL limitations, and fewer depressive symptoms. The point estimates presented in Table 3 represent a 1 percent decrease in self-rated health, a 4.1 percent in ADLs, a 5.2 percent decrease in IADLs and a 2.1 percent decrease in the CESD score.

As discussed above, these estimates do not represent causal effects due to unobserved factors that may be correlated with both income and health outcomes. Therefore, we account for the endogeneity of income using the IV models represented by equations (2) and (3). In Table 4, we present results for the cognition measures. Column (1) presents the first stage results, while columns 2 to 5 present the second stage results for each of the cognition measures. The first stage results show that the instrument is strongly correlated with Social Security income and the F-statistic from the test of weak instruments is 13.3, above the commonly accepted threshold of 10. Conditional on other covariates, individuals born between 1915 and 1917 have annual Social Security income approximately $\$ 700$ greater than other cohorts. Accounting for the endogeneity of income, we find a significant positive impact of Social Security income on all four measures of cognitive function. Relative to the sample mean, there is a 4.8 percent increase in the serial 7 score, a 6.6 percent increase in the recall score, a 2.1 percent increase in the mental status score, and a 3.9 percent increase in the total cognition score. The IV models identify a larger effect than the OLS models, which may be due to measurement error in self-reported Social Security income which would bias OLS estimates towards zero. It is also plausible that unobserved factors are correlated with income and cognition in ways that bias OLS estimates downwards.

Table 5 presents results from the IV models for self-rated health, disability and depression. There is no longer a significant effect of income on self-rated health, suggesting that the correlation identified by OLS models may be driven by unobserved confounders. We also estimated OLS and IV models using the binary indicator for fair or poor self-rated health (not shown). Results were similar to the ones obtained using the continuous measure. In contrast, we do find a significant reduction in functional limitations even after accounting for the endogeneity of income. Relative to the sample mean, there is a 15.8 percent reduction in the number of ADL 
limitations and a 15.7 percent decline in the number of IADL limitations. We also find a 9.1 percent decrease in the number of depressive symptoms; however, this estimate is only significant at the 10 percent level.

In Tables 6 and 7, we explore heterogeneous effect by educational attainment. Specifically, we estimate separate regressions for households whose primary Social Security beneficiary has less than a high school education and for households whose primary beneficiary has a high school degree or higher education. Heterogeneity by education is important for two reasons. First, the 1977 amendments also increased the covered earnings maximum used to calculate the "average indexed monthly earnings" (AIME), which summarizes up to 35 years of a worker's indexed earnings and is used to determine benefits. As a result of this change, the notch had a larger effect on persons with less than a high school education (Goda, Golberstein, and Grabowski 2011). Secondly, education is well known to be strongly correlated with health. Therefore, Social Security benefits may differentially affect the health of low-education households compared to high-education households. Table 6 shows that the impact of income on cognition does vary by education. For serial 7, mental status, and total cognition, we find that Social Security income has a positive impact on cognition for households whose primary beneficiary has less than a high school degree. For households whose primary beneficiary is a high school graduate, Social Security income does not have a statistically significant influence on cognition for any of the measures, although the point estimates are larger than the point estimates for low-education households for word recall and total cognition.

We do not find significant effects of income on self-rated health or disability when we stratify the sample by education (Table 7). However, in the case of CESD score, there is a large and significant effect of income for low-education households. In contrast, the estimate for high=education households is small in magnitude and statistically insignificant. Further, we evaluate the extent to which these decreases in the number of depressive symptoms represent clinically meaningful improvements in mental health. Using a binary indicator of three or more depressive symptoms, we find that a $\$ 1,000$ increase in Social Security income decreases the probability of three or more depressive symptoms by 2 percentage points (or 8 percent relative to the sample mean) in the full sample (not shown). This effect is significant at the 10 percent level. Consistent with the results using the continuous CESD measure, we find that higher Social Security benefits are associated with a large, significant decline in the likelihood of 
depression among households whose primary beneficiary has less than a high school education. Specifically, for these households, a \$1000 increase in Social Security income led to a 5.8 percentage point (18.5 percent) drop in the probability of having three or more depressive symptoms. In contrast, the effect for high-education households is statistically insignificant.

Finally, we assess the extent to which the impact of income varies at different levels of cognition using an instrumental variable quantile regression model. The results presented in Table 8 show that there is a larger effect of income at higher quantiles. At the $10^{\text {th }}$ quantile, a $\$ 1000$ increase in Social Security income is associated with a 0.6 unit increase in the total cognition score, while at the $90^{\text {th }}$ quantile a similar amount of income results in a 6.7 increase in the total cognition score. Thus, while higher Social Security benefits are beneficial to all groups, individuals with better cognition benefit more from increases in income. This suggests that disparities in cognition increase sharply with income.

\section{Conclusion}

Using data from a nationally representative survey of older adults, we find that higher Social Security income significantly improves health outcomes among the elderly. Specifically, we find that increases in annual Social Security benefits led to significant improvements in functional limitations and cognitive function, and that the improvements in cognition function were larger for individuals with better cognition. We also find significant improvements in mental health, but only in the subsample of households whose primary beneficiary has less than a high school education. In contrast, we do not find any significant improvements in self-rated health. By using a quasi-experimental approach based on amendments to the Social Security Act in the 1970s, this study is able to address several limitations of prior literature on the relationship between income and health, including unmeasured confounders and reverse causality.

The findings of our study have important implications for aging populations and for public policy. As discussed above, several proposals that would change Social Security benefits in order to address the financial solvency of the Social Security Trust Fund are currently under consideration by policymakers. During a period of renewed policy discussion around changes to entitlement programs for the elderly, it is important to understand whether changes to Social Security might influence the health and well-being of the elderly. Our findings suggest that reductions to Social Security benefits could potentially have significant negative impacts on the 
functional limitations and cognitive function of older adults, while increases in benefits could lead to improvements in health outcomes. In addition to the direct impact on population health, changes in Social Security benefits may also affect public health insurance programs such as Medicaid and Medicare since functional limitations and cognitive impairments are often associated with significant health care spending. Thus, any increased program outlays on Social Security benefits could potentially be offset by reduced health care expenditures by the Medicaid or Medicare program. However, further research is necessary to fully understand the net impact of changes to Social Security benefits on aggregate spending by federal and state governments. 


\section{References}

Almond, Douglas and Janet Currie. 2011. "Killing Me Softly: The Fetal Origins Hypothesis.” Journal of Economic Perspectives 25(3): 153-72.

Alzheimer’s Association Report. 2012. “2012 Alzheimer’s Disease Facts and Figures.” Alzheimer’s \& Dementia 8(2): 131-168.

Ayyagari, P., M. Salm, and F. A. Sloan. 2007. "Effects of Diagnosed Dementia on Medicare and Medicaid Program Costs.” Inquiry 44(4): 481-494.

Ayyagari, Padmaja and Dan M. Shane. 2015. "Does Prescription Drug Coverage Improve Mental Health? Evidence from Medicare Part D.” Journal of Health Economics 41: 4658.

Bonsang, Eric, Stéphane Adam, and Sergio Perelman. 2012. "Does Retirement Affect Cognitive Functioning?” Journal of Health Economics 31(3): 490-501.

Cawley, John, John Moran, and Kosali Simon. 2010. “The Impact of Income on the Weight of Elderly Americans.” Health Economics 19(8): 979-993.

Charles, K. K. 2004. “Is Retirement Depressing?: Labor Force Inactivity and Psychological Well-Being in Later Life.” Research in Labor Economics 23: 269-299.

Chernozhukov, Victor and Christian Hansen. 2008. "Instrumental Variable Quantile Regression: A Robust Inference Approach.” Journal of Econometrics 142(1): 379-398.

Daviglus, M. L., C. C. Bell, W. Berrettini, P. E. Bowen, E. S. Connolly, N. J. Cox, J. M. DunbarJacob, E. C. Granieri, G. Hunt, and K. McGarry. 2010. "NIH State-of-the-Science Conference Statement: Preventing Alzheimer’s Disease and Cognitive Decline.” NIH Consensus and State-of-the-Science Statements 27(4): 1-30.

Engelhardt, Gary V., Jonathan Gruber, and Cynthia D. Perry. 2005. "Social Security and Elderly Living Arrangements: Evidence from the Social Security Notch.” Journal of Human Resources XL (2): 354-372.

Ettner, Susan L. 1997. "Adverse Selection and the Purchase of Medigap Insurance by the Elderly.” Journal of Health Economics 16(5): 543-562.

Fang, Hanming, Michael P. Keane, and Dan Silverman. 2008. "Sources of Advantageous Selection: Evidence from the Medigap Insurance Market.” Journal of Political Economy 116(2): 303-350. -

Fisher, G. G., H. Hassan, W. L. Rodgers, and D. R. Weir. 2012. "Health and Retirement Study Imputation of Cognitive Functioning Measures: 1992-2010 Early Release.” Ann Arbor, MI: Survey Research Center. 
French, Eric. 2005. “The Effects of Health, Wealth, and Wages on Labour Supply and Retirement Behaviour.” The Review of Economic Studies 72(2): 395-427.

Goda, Gopi Shah, Ezra Golberstein, and David C Grabowski. 2011. “Income and the Utilization of Long-Term Care Services: Evidence from the Social Security Benefit Notch.” Journal of Health Economics 30(4): 719-729.

Herzog, A. Regula and Robert B. Wallace. 1997. "Measures of Cognitive Functioning in the AHEAD Study.” The Journals of Gerontology Series B: Psychological Sciences and Social Sciences 52(Special Issue): 37-48.

Hurd, Michael D., Paco Martorell, Adeline Delavande, Kathleen J. Mullen, and Kenneth M. Langa. 2013. "Monetary Costs of Dementia in the United States.” New England Journal of Medicine 368(14): 1326-1334.

Krueger, Alan B. and Jorn-Steffen Pischke. 1992. "The Effect of Social Security on Labor Supply: A Cohort Analysis of the Notch Generation.” Journal of Labor Economics 10(4): 412-37.

Mazzonna, Fabrizio and Franco Peracchi. 2012. “Ageing, Cognitive Abilities and Retirement.” European Economic Review 56(4): 691-710.

McInerney, Melissa, Jennifer M. Mellor, and Lauren Hersch Nicholas. 2013. "Recession Depression: Mental Health Effects of the 2008 Stock Market Crash.” Journal of Health Economics 32(6): 1090-1104.

Mendes De Leon, Carlos F., Stephen S. Rapp, and Stanislav V. Kasl. 1994. "Financial Strain and Symptoms of Depression in a Community Sample of Elderly Men and Women: A Longitudinal Study.” Journal of Aging and Health 6(4): 448-468.

Moran, John R and Kosali Ilayperuma Simon. 2006. "Income and the Use of Prescription Drugs by the Elderly Evidence from the Notch Cohorts.” Journal of Human Resources 41(2): 411-432.

Ofstedal, M. B., G. G. Fisher, and A. R. Herzog. 2005. "Documentation of Cognitive Functioning Measures in the Health and Retirement Study.” Ann Arbor, MI: University of Michigan.

Rohwedder, Susann and Robert J. Willis. 2010. “Mental Retirement.” Journal of Economic Perspectives 24(1): 119-38.

Smith, James P. 1999. "Healthy Bodies and Thick Wallets: The Dual Relation between Health and Economic Status.” Journal of Economic Perspectives 13(2): 145-166.

Snyder, Stephen E. and William N. Evans. 2006. “The Effect of Income on Mortality: Evidence from the Social Security Notch.” The Review of Economics and Statistics 88(3): 482-495. 
Springstead, Glenn R., Kevin Whitman, and Dave Shoffner. 2014. "Proposed Revisions to the Special Minimum Benefit for Low Lifetime Earners.” Social Security Administration Policy Brief 2014-01. Washington, D.C.: U.S. Social Security Administration.

Staiger, Douglas and James H. Stock. 1997. “Instrumental Variables Regression with Weak Instruments.” Econometrica 65(3): 557-586.

Stock, James and Motohiro Yogo. 2005. “Testing for Weak Instruments in Linear IV Regression.” in Identification and Inference for Econometric Models: Essays In Honor of Thomas Rothenberg. New York: Cambridge University Press: 80-108.

Unützer, Jürgen, Michael Schoenbaum, Wayne J. Katon, Ming-Yu Fan, Harold A. Pincus, Diane Hogan, and Jennifer Taylor. 2009. "Healthcare Costs Associated with Depression in Medically Ill Fee-for-Service Medicare Participants.” Journal of the American Geriatrics Society 57(3): 506-510.

Van der Klaauw, Wilbert and Kenneth I. Wolpin. 2008. "Social Security and the Retirement and Savings Behavior of Low-Income Households.” Journal of Econometrics 145(1-2): 2142. 
Figure 1. Histograms of Cognitive Function Measures
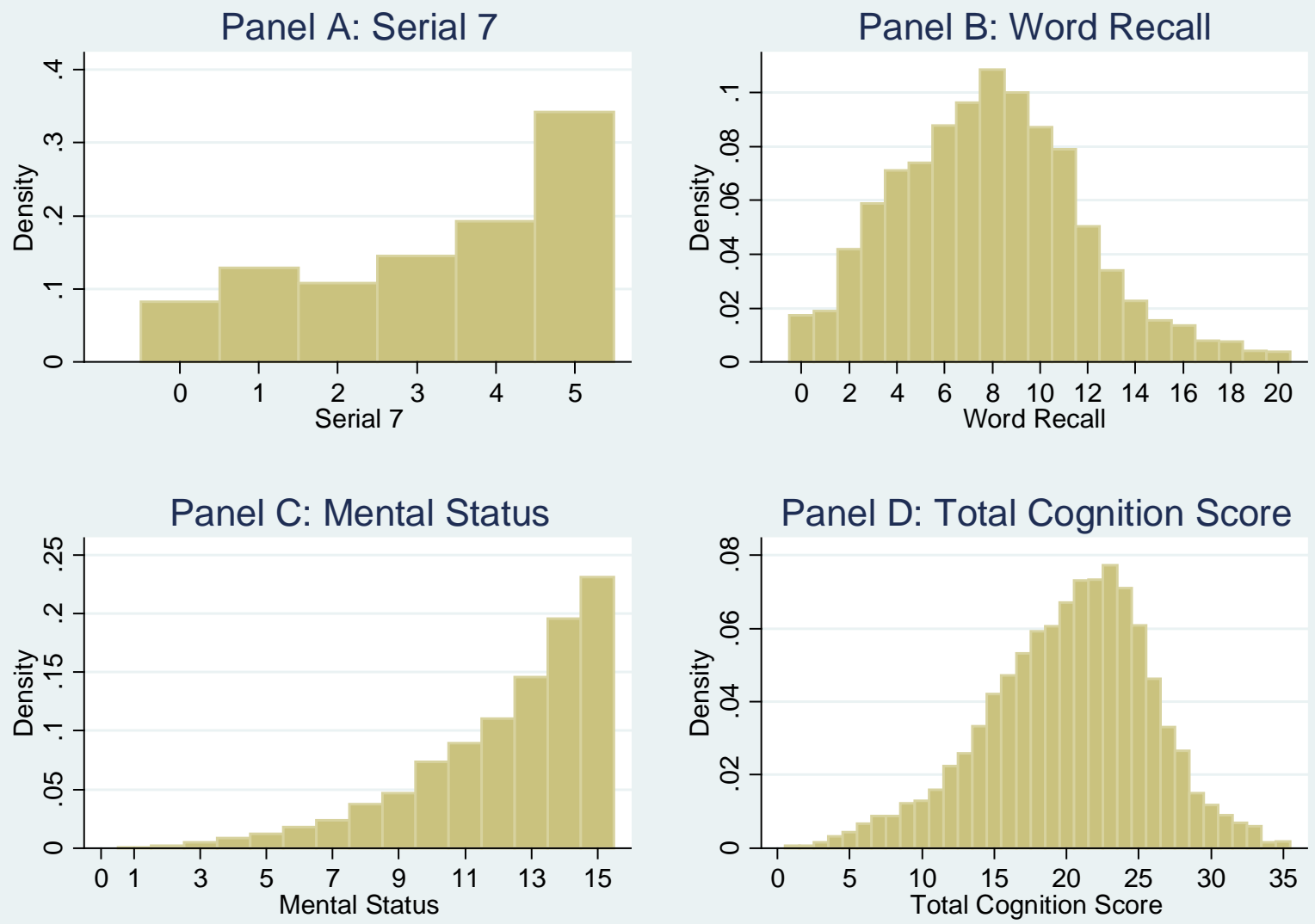
Figure 2. Histograms of Physical and Mental Health Measures
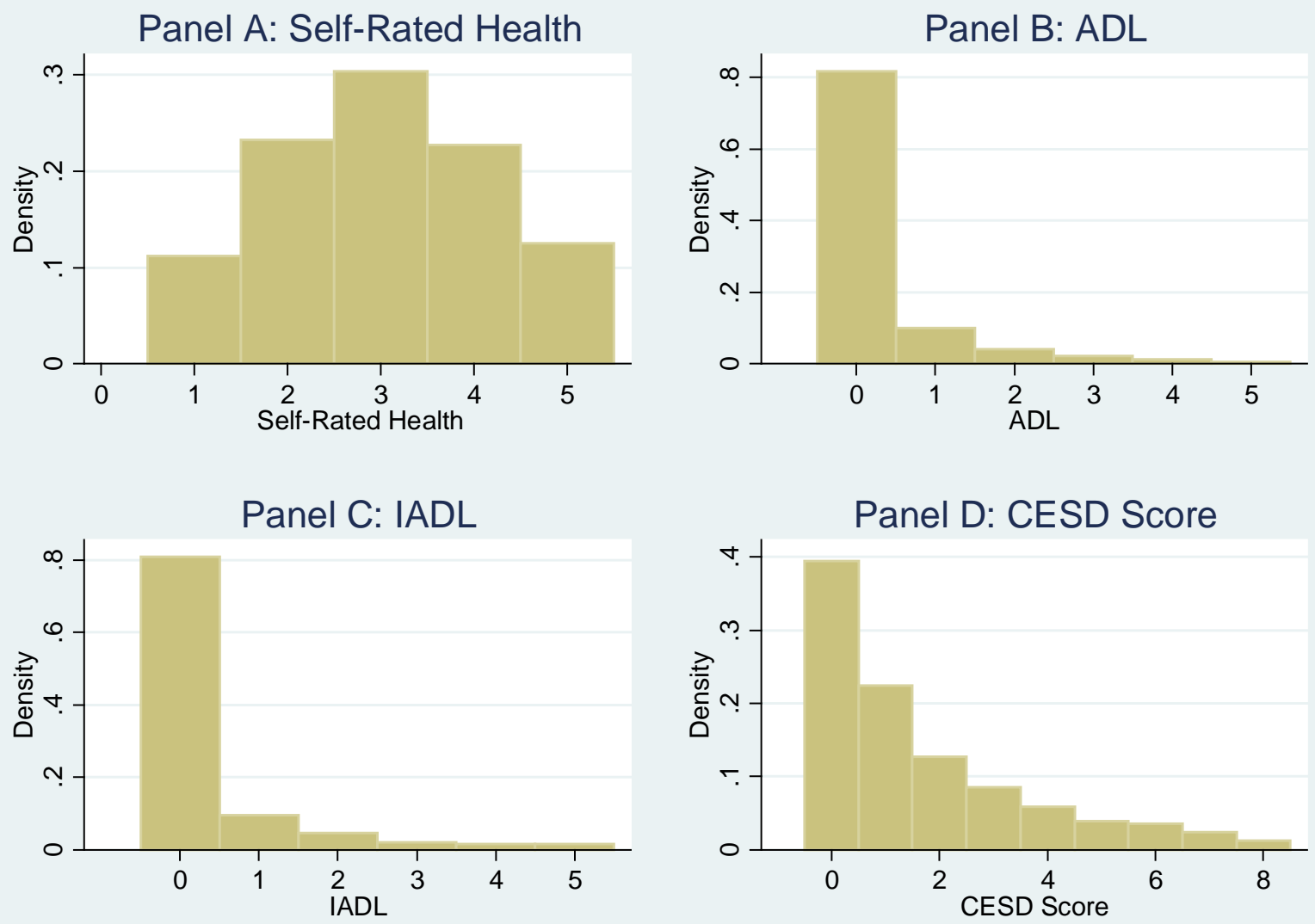


\begin{tabular}{|c|c|c|c|}
\hline & (1) & (2) & (3) \\
\hline & Full sample & $\begin{array}{l}\text { 1915-1917 } \\
\text { cohort (IV) }\end{array}$ & $\begin{array}{c}\text { Other birth } \\
\text { years }\end{array}$ \\
\hline \multirow[t]{2}{*}{ Serial 7} & 3.2623 & 3.3991 & 3.2336 \\
\hline & (1.6918) & (1.6503) & $(1.6992)$ \\
\hline \multirow[t]{2}{*}{ Word recall } & 7.8834 & 8.4066 & 7.7734 \\
\hline & (3.8703) & $(3.7720)$ & $(3.8820)$ \\
\hline \multirow[t]{2}{*}{ Mental status } & 12.2620 & 12.5330 & 12.2050 \\
\hline & (2.7099) & $(2.4572)$ & $(2.7569)$ \\
\hline \multirow[t]{2}{*}{ Total cognition score } & 20.1454 & 20.9396 & 19.9784 \\
\hline & $(5.6614)$ & $(5.2330)$ & $(5.7340)$ \\
\hline \multirow{2}{*}{ Self-rated health } & 3.0220 & 3.0293 & 3.0206 \\
\hline & $(1.1867)$ & $(1.1765)$ & (1.1889) \\
\hline \multirow[t]{2}{*}{ ADL } & 0.3352 & 0.2775 & 0.3470 \\
\hline & $(0.8519)$ & $(0.7746)$ & $(0.8664)$ \\
\hline \multirow[t]{2}{*}{ IADL } & 0.3908 & 0.2970 & 0.4101 \\
\hline & $(0.9827)$ & $(0.8412)$ & $(1.0082)$ \\
\hline \multirow[t]{2}{*}{ CESD score } & 1.6358 & 1.5377 & 1.6564 \\
\hline & $(1.9844)$ & (1.9189) & $(1.9975)$ \\
\hline \multirow[t]{2}{*}{ Annual SS income ${ }^{a}$} & 10.8135 & 11.1612 & 10.7404 \\
\hline & $(5.1330)$ & $(5.5231)$ & $(5.0447)$ \\
\hline \multirow[t]{2}{*}{ Primary beneficiaries’ age } & 77.7357 & 76.9632 & 77.8982 \\
\hline & (5.6568) & $(0.8128)$ & $(6.2001)$ \\
\hline \multirow[t]{2}{*}{ Male head-married } & 0.5678 & 0.5236 & 0.5771 \\
\hline & $(0.4954)$ & $(0.4997)$ & $(0.4941)$ \\
\hline \multirow[t]{2}{*}{ Male head-single } & 0.0935 & 0.0962 & 0.0929 \\
\hline & $(0.2911)$ & $(0.2950)$ & $(0.2903)$ \\
\hline \multirow{2}{*}{ Female head-never married } & 0.0174 & 0.0151 & 0.0179 \\
\hline & $(0.1307)$ & $(0.1220)$ & $(0.1325)$ \\
\hline \multirow[t]{2}{*}{ Female head-widowed } & 0.2889 & 0.3189 & 0.2826 \\
\hline & $(0.4533)$ & $(0.4663)$ & $(0.4503)$ \\
\hline \multirow[t]{2}{*}{ MSA/Urban area } & 0.7508 & 0.7311 & 0.7549 \\
\hline & $(0.4326)$ & $(0.4436)$ & $(0.4302)$ \\
\hline \multirow[t]{2}{*}{ Mid Atlantic } & 0.1399 & 0.1519 & 0.1373 \\
\hline & $(0.3469)$ & $(0.3591)$ & $(0.3442)$ \\
\hline \multirow[t]{2}{*}{ EN Central } & 0.1874 & 0.1981 & 0.1852 \\
\hline & $(0.3903)$ & $(0.3988)$ & $(0.3885)$ \\
\hline \multirow[t]{2}{*}{ WN Central } & 0.0795 & 0.0774 & 0.0800 \\
\hline & $(0.2706)$ & $(0.2673)$ & $(0.2713)$ \\
\hline \multirow[t]{2}{*}{ S Atlantic } & 0.2351 & 0.2142 & 0.2395 \\
\hline & $(0.4241)$ & $(0.4104)$ & $(0.4268)$ \\
\hline \multirow[t]{2}{*}{ ES Central } & 0.0361 & 0.0321 & 0.0369 \\
\hline & $(0.1865)$ & $(0.1763)$ & $(0.1886)$ \\
\hline
\end{tabular}

-Continued- 
Table 1. Summary Statistics (cont'd)

\begin{tabular}{lccc}
\hline & $(1)$ & $(2)$ & $(3)$ \\
\cline { 2 - 4 } & Full sample & $\begin{array}{c}1915-1917 \\
\text { cohort (IV) }\end{array}$ & $\begin{array}{c}\text { Other birth } \\
\text { years }\end{array}$ \\
\hline WS Central & 0.1099 & 0.1094 & 0.1099 \\
& $(0.3127)$ & $(0.3123)$ & $(0.3129)$ \\
Mountain & 0.0413 & 0.0340 & 0.0429 \\
& $(0.1990)$ & $(0.1812)$ & $(0.2026)$ \\
Pacific & 0.1294 & 0.1396 & 0.1272 \\
& $(0.3356)$ & $(0.3468)$ & $(0.3332)$ \\
Primary beneficiary's race - Hispanic & 0.0351 & 0.0255 & 0.0371 \\
& $(0.1840)$ & $(0.1576)$ & $(0.1891)$ \\
Primary beneficiary's race - Black & 0.0671 & 0.0491 & 0.0709 \\
& $(0.2502)$ & $(0.2161)$ & $(0.2566)$ \\
Primary beneficiary's race - Other & 0.0113 & 0.0113 & 0.0113 \\
& $(0.1058)$ & $(0.1059)$ & $(0.1058)$ \\
Own age & 75.7459 & 74.8132 & 75.9421 \\
& $(6.1170)$ & $(3.2814)$ & $(6.5426)$ \\
Male & 0.3750 & 0.3528 & 0.3796 \\
& $(0.4842)$ & $(0.4781)$ & $(0.4853)$ \\
\hline $\mathrm{N}$ & 6,099 & 1,060 & 5,039 \\
\hline
\end{tabular}

${ }^{a}$ in ‘000s 1993 USD. 
Table 2. Impact of Social Security Income on Cognitive Function (OLS)

\begin{tabular}{|c|c|c|c|c|}
\hline & $(1)$ & (2) & (3) & (4) \\
\hline & Serial 7 & $\begin{array}{l}\text { Word } \\
\text { recall }\end{array}$ & $\begin{array}{l}\text { Mental } \\
\text { status }\end{array}$ & $\begin{array}{c}\text { Total } \\
\text { cognition } \\
\text { score }\end{array}$ \\
\hline Annual SS income $^{a}$ & $\begin{array}{c}0.0468 * * * \\
(0.0067)\end{array}$ & $\begin{array}{c}0.0913 * * * \\
(0.0128)\end{array}$ & $\begin{array}{c}0.0930 * * * \\
(0.0115)\end{array}$ & $\begin{array}{c}0.1843 * * * \\
(0.0218)\end{array}$ \\
\hline Primary beneficiary's age & $\begin{array}{c}-0.0176^{* *} \\
(0.0068)\end{array}$ & $\begin{array}{c}-0.0443 * * \\
(0.0191)\end{array}$ & $\begin{array}{c}-0.0439 * * * \\
(0.0118)\end{array}$ & $\begin{array}{c}-0.0882 * * * \\
(0.0278)\end{array}$ \\
\hline Male head - married & $\begin{array}{l}0.3586^{*} \\
(0.1813)\end{array}$ & $\begin{array}{c}0.1253 \\
(0.2903)\end{array}$ & $\begin{array}{c}0.4395 \\
(0.2809)\end{array}$ & $\begin{array}{c}0.5648 \\
(0.5182)\end{array}$ \\
\hline Male head - single & $\begin{array}{c}0.4667^{* * *} \\
(0.1630)\end{array}$ & $\begin{array}{c}0.1736 \\
(0.3046)\end{array}$ & $\begin{array}{c}0.5979 * * \\
(0.2740)\end{array}$ & $\begin{array}{c}0.7716 \\
(0.5047)\end{array}$ \\
\hline Female head-never married & $\begin{array}{c}0.6549 * * \\
(0.2418)\end{array}$ & $\begin{array}{c}0.3200 \\
(0.4042)\end{array}$ & $\begin{array}{l}0.7752 * \\
(0.3855)\end{array}$ & $\begin{array}{c}1.0951 \\
(0.7273)\end{array}$ \\
\hline Female head-widowed & $\begin{array}{c}0.3650 * * \\
(0.1540)\end{array}$ & $\begin{array}{l}-0.0151 \\
(0.2990)\end{array}$ & $\begin{array}{c}0.4066 \\
(0.2403)\end{array}$ & $\begin{array}{c}0.3914 \\
(0.4927)\end{array}$ \\
\hline MSA/Urban area & $\begin{array}{c}0.1548 * * \\
(0.0609)\end{array}$ & $\begin{array}{c}0.3536 * * * \\
(0.1138)\end{array}$ & $\begin{array}{c}0.2401 * * \\
(0.1018)\end{array}$ & $\begin{array}{c}0.5937 * * * * \\
(0.1905)\end{array}$ \\
\hline Mid Atlantic & $\begin{array}{c}0.0047 \\
(0.0895)\end{array}$ & $\begin{array}{c}-0.4043^{*} \\
(0.2368)\end{array}$ & $\begin{array}{c}0.0667 \\
(0.1218)\end{array}$ & $\begin{array}{l}-0.3376 \\
(0.2634)\end{array}$ \\
\hline EN Central & $\begin{array}{c}-0.0232 \\
(0.0985)\end{array}$ & $\begin{array}{l}-0.0626 \\
(0.2781)\end{array}$ & $\begin{array}{c}0.0017 \\
(0.1399)\end{array}$ & $\begin{array}{c}-0.0609 \\
(0.3425)\end{array}$ \\
\hline WN Central & $\begin{array}{c}0.1259 \\
(0.0787)\end{array}$ & $\begin{array}{c}0.4103 \\
(0.3776)\end{array}$ & $\begin{array}{c}0.2382 * * \\
(0.1082)\end{array}$ & $\begin{array}{c}0.6486 \\
(0.4381)\end{array}$ \\
\hline S Atlantic & $\begin{array}{l}-0.1691 \\
(0.1151)\end{array}$ & $\begin{array}{l}-0.1632 \\
(0.2329)\end{array}$ & $\begin{array}{c}-0.3344 * * \\
(0.1464)\end{array}$ & $\begin{array}{l}-0.4976^{*} \\
(0.2757)\end{array}$ \\
\hline ES Central & $\begin{array}{c}-0.3789 * * \\
(0.1816)\end{array}$ & $\begin{array}{c}-0.3393 \\
(0.3828)\end{array}$ & $\begin{array}{l}-0.4495 \\
(0.2682)\end{array}$ & $\begin{array}{l}-0.7887 \\
(0.5927)\end{array}$ \\
\hline WS Central & $\begin{array}{c}-0.3120 * * * \\
(0.1014)\end{array}$ & $\begin{array}{c}-0.6395^{*} \\
(0.3189)\end{array}$ & $\begin{array}{c}-0.5885 * * * \\
(0.1909)\end{array}$ & $\begin{array}{c}-1.2280^{* *} \\
(0.4515)\end{array}$ \\
\hline Mountain & $\begin{array}{l}0.2066^{*} \\
(0.1155)\end{array}$ & $\begin{array}{c}1.1275^{* * * *} \\
(0.3569)\end{array}$ & $\begin{array}{c}0.4175^{* *} \\
(0.1811)\end{array}$ & $\begin{array}{c}1.5449 * * * * \\
(0.4093)\end{array}$ \\
\hline Pacific & $\begin{array}{l}0.1606^{*} \\
(0.0903)\end{array}$ & $\begin{array}{l}0.5305^{* *} \\
(0.2219)\end{array}$ & $\begin{array}{c}0.4371^{* * *} \\
(0.1023)\end{array}$ & $\begin{array}{c}0.9676^{* * * *} \\
(0.2856)\end{array}$ \\
\hline Primary beneficiary's race - Hispanic & $-1.0440 * * *$ & $\begin{array}{c}- \\
1.3782 * * * \\
(0.2638)\end{array}$ & $-1.9119 * * *$ & $\begin{array}{c}-3.2901 * * * \\
(0.4697)\end{array}$ \\
\hline Primary beneficiary's race - Black & $-1.3435 * * *$ & $\begin{array}{c}- \\
1.8184^{* * *} \\
(0.1240)\end{array}$ & $-2.5263 * * *$ & $-4.3447^{* * *}$ \\
\hline Primary beneficiary's race - Other & $\begin{array}{l}-0.4069 * \\
(0.2085)\end{array}$ & $\begin{array}{c}-0.8798^{*} \\
(0.4474)\end{array}$ & $\begin{array}{c}-0.8992 * * \\
(0.4039)\end{array}$ & $\begin{array}{c}-1.7790 * * \\
(0.7446)\end{array}$ \\
\hline
\end{tabular}

-Continued- 
Table 2. Impact of Social Security Income on Cognitive Function (OLS) (cont’d)

\begin{tabular}{lcccc}
\hline & $(1)$ & $(2)$ & $(3)$ & $(4)$ \\
\cline { 2 - 5 } & Serial 7 & $\begin{array}{c}\text { Word } \\
\text { recall }\end{array}$ & $\begin{array}{c}\text { Mental } \\
\text { status }\end{array}$ & $\begin{array}{c}\text { Total } \\
\text { cognition } \\
\text { score }\end{array}$ \\
\hline Own age & $-0.0232^{* * *}$ & - & $-0.0558^{* * *}$ & $-0.2248^{* * *}$ \\
& & $0.1691^{* * *}$ & & \\
Male & $(0.0066)$ & $(0.0200)$ & $(0.0107)$ & $(0.0277)$ \\
& $0.3736^{* * *}$ & - & $0.3142^{* * *}$ & $-0.6212^{* * *}$ \\
Constant & $(0.0470)$ & $\begin{array}{c}0.9353^{* * *} \\
(0.1432)\end{array}$ & $(0.0805)$ & $(0.1838)$ \\
& $5.4460^{* * *}$ & $23.3604 * *$ & $18.4614 * *$ & $41.8218 * * *$ \\
$\mathrm{~N}$ & $(0.4183)$ & $(1.0301)$ & $(0.7218)$ & $(1.5747)$ \\
\hline
\end{tabular}

${ }^{\mathrm{a}}$ in '000s 1993 USD.

Notes: ${ }^{*} \mathrm{p}<0.10,{ }^{* *} \mathrm{p}<0.05,{ }^{* * *} \mathrm{p}<0.01$. Robust standard errors in parentheses are clustered at the year-of-birth level. 
Table 3. Impact of Social Security Income on Physical and Mental Health (OLS)

\begin{tabular}{|c|c|c|c|c|}
\hline & $(1)$ & (2) & (3) & (4) \\
\hline & $\begin{array}{l}\text { Self-rated } \\
\text { health }\end{array}$ & ADL & IADL & CESD \\
\hline Annual SS income $^{a}$ & $\begin{array}{c}-0.0299 * * * \\
(0.0042)\end{array}$ & $\begin{array}{c}-0.0137 * * * \\
(0.0025)\end{array}$ & $\begin{array}{c}-0.0201 * * * \\
(0.0033)\end{array}$ & $\begin{array}{c}-0.0339 * * * \\
(0.0063)\end{array}$ \\
\hline Primary beneficiary’s age & $\begin{array}{c}0.0057 \\
(0.0044)\end{array}$ & $\begin{array}{c}0.0046 \\
(0.0045)\end{array}$ & $\begin{array}{c}0.0086 \\
(0.0051)\end{array}$ & $\begin{array}{c}0.0203 * * * \\
(0.0073)\end{array}$ \\
\hline Male head-married & $\begin{array}{c}0.0178 \\
(0.0750)\end{array}$ & $\begin{array}{l}-0.0360 \\
(0.0708)\end{array}$ & $\begin{array}{c}0.2839 * * * \\
(0.0621)\end{array}$ & $\begin{array}{l}-0.2259 * \\
(0.1271)\end{array}$ \\
\hline Male head-single & $\begin{array}{c}-0.2544 * * * \\
(0.0739)\end{array}$ & $\begin{array}{l}-0.0662 \\
(0.0826)\end{array}$ & $\begin{array}{c}0.0275 \\
(0.0677)\end{array}$ & $\begin{array}{l}0.2963 * \\
(0.1494)\end{array}$ \\
\hline Female head - never married & $\begin{array}{l}-0.2113 \\
(0.1415)\end{array}$ & $\begin{array}{l}-0.1943 * \\
(0.1076)\end{array}$ & $\begin{array}{c}0.0913 \\
(0.1047)\end{array}$ & $\begin{array}{c}-0.4978 * * \\
(0.1912)\end{array}$ \\
\hline Female head - widowed & $\begin{array}{l}-0.0017 \\
(0.0628)\end{array}$ & $\begin{array}{l}-0.0570 \\
(0.0629)\end{array}$ & $\begin{array}{c}0.1488 * * * \\
(0.0532)\end{array}$ & $\begin{array}{l}-0.0429 \\
(0.1137)\end{array}$ \\
\hline MSA/Urban area & $\begin{array}{c}-0.1159 * * * \\
(0.0357)\end{array}$ & $\begin{array}{l}-0.0064 \\
(0.0251)\end{array}$ & $\begin{array}{c}0.0071 \\
(0.0299)\end{array}$ & $\begin{array}{l}-0.0083 \\
(0.0635)\end{array}$ \\
\hline Mid Atlantic & $\begin{array}{l}-0.0161 \\
(0.0899)\end{array}$ & $\begin{array}{c}0.0437 \\
(0.0445)\end{array}$ & $\begin{array}{c}0.0730 \\
(0.0491)\end{array}$ & $\begin{array}{l}-0.0419 \\
(0.1671)\end{array}$ \\
\hline EN Central & $\begin{array}{l}-0.0201 \\
(0.0786)\end{array}$ & $\begin{array}{c}0.0419 \\
(0.0483)\end{array}$ & $\begin{array}{c}0.0627 \\
(0.0480)\end{array}$ & $\begin{array}{l}-0.2395 \\
(0.1476)\end{array}$ \\
\hline WN Central & $\begin{array}{l}-0.1812^{*} \\
(0.0915)\end{array}$ & $\begin{array}{c}0.0100 \\
(0.0529)\end{array}$ & $\begin{array}{c}0.0600 \\
(0.0440)\end{array}$ & $\begin{array}{c}-0.5291^{* * *} \\
(0.1566)\end{array}$ \\
\hline S Atlantic & $\begin{array}{l}-0.0717 \\
(0.0733)\end{array}$ & $\begin{array}{c}0.0662 \\
(0.0412)\end{array}$ & $\begin{array}{c}0.0794 \\
(0.0532)\end{array}$ & $\begin{array}{l}-0.2329 \\
(0.1511)\end{array}$ \\
\hline ES Central & $\begin{array}{c}0.1619 \\
(0.1033)\end{array}$ & $\begin{array}{c}0.0236 \\
(0.0683)\end{array}$ & $\begin{array}{c}0.3351 * * * \\
(0.1027)\end{array}$ & $\begin{array}{l}-0.1843 \\
(0.1769)\end{array}$ \\
\hline WS Central & $\begin{array}{c}0.0813 \\
(0.0684)\end{array}$ & $\begin{array}{c}0.2478 * * * \\
(0.0525)\end{array}$ & $\begin{array}{c}0.2269 * * * \\
(0.0697)\end{array}$ & $\begin{array}{l}0.2635 * \\
(0.1401)\end{array}$ \\
\hline Mountain & $\begin{array}{c}-0.3123^{* * *} \\
(0.1000)\end{array}$ & $\begin{array}{l}-0.0064 \\
(0.0474)\end{array}$ & $\begin{array}{c}0.0054 \\
(0.0569)\end{array}$ & $\begin{array}{c}-0.2780 \\
(0.2001)\end{array}$ \\
\hline Pacific & $\begin{array}{c}-0.2028 * * * \\
(0.0722)\end{array}$ & $\begin{array}{l}-0.0011 \\
(0.0394)\end{array}$ & $\begin{array}{c}0.0048 \\
(0.0506)\end{array}$ & $\begin{array}{c}-0.4010 * * * \\
(0.1452)\end{array}$ \\
\hline Primary beneficiary’s race - Hispanic & $\begin{array}{c}0.3708^{* * *} \\
(0.1088)\end{array}$ & $\begin{array}{c}0.1474 \\
(0.0908)\end{array}$ & $\begin{array}{c}0.2201 * * * \\
(0.0792)\end{array}$ & $\begin{array}{c}0.8198 * * * \\
(0.2000)\end{array}$ \\
\hline Primary beneficiary’s race - Black & $\begin{array}{c}0.4070 * * * \\
(0.0560)\end{array}$ & $\begin{array}{l}0.0943 * \\
(0.0461)\end{array}$ & $\begin{array}{c}0.2787 * * * \\
(0.0778)\end{array}$ & $\begin{array}{c}0.3252 * * * \\
(0.0975)\end{array}$ \\
\hline Primary beneficiary’s race - Other & $\begin{array}{l}0.3346 * * \\
(0.1424)\end{array}$ & $\begin{array}{c}0.0894 \\
(0.1105)\end{array}$ & $\begin{array}{c}0.1639 \\
(0.0992)\end{array}$ & $\begin{array}{c}0.4549 \\
(0.2878)\end{array}$ \\
\hline Own age & $\begin{array}{c}0.0176 * * * \\
(0.0034)\end{array}$ & $\begin{array}{c}0.0163 * * * \\
(0.0031)\end{array}$ & $\begin{array}{c}0.0306 * * * \\
(0.0045)\end{array}$ & $\begin{array}{l}0.0111^{*} \\
(0.0061)\end{array}$ \\
\hline Male & $\begin{array}{c}0.0702 * * \\
(0.0334)\end{array}$ & $\begin{array}{c}-0.0642 * * * \\
(0.0180)\end{array}$ & $\begin{array}{c}-0.0545 * * \\
(0.0259)\end{array}$ & $\begin{array}{c}-0.3462^{* * *} \\
(0.0471)\end{array}$ \\
\hline
\end{tabular}

-Continued- 
Table 3. Impact of Social Security Income on Physical and Mental Health (OLS) (cont'd)

\begin{tabular}{|c|c|c|c|c|}
\hline & (1) & $(2)$ & (3) & (4) \\
\hline & $\begin{array}{l}\text { Self-rated } \\
\text { health }\end{array}$ & ADL & IADL & CESD \\
\hline Constant & $\begin{array}{c}1.6589 * * * \\
(0.2638)\end{array}$ & $\begin{array}{c}-1.1057 * * * \\
(0.2389) \\
\end{array}$ & $\begin{array}{c}-2.6941 * * * \\
(0.2402)\end{array}$ & $\begin{array}{r}-0.0275 \\
(0.4147) \\
\end{array}$ \\
\hline $\mathrm{N}$ & 6,627 & 6,632 & 6,632 & 6,098 \\
\hline
\end{tabular}

${ }^{\mathrm{a}}$ in '000s 1993 USD

Notes: $\mathrm{p}<0.10,{ }^{* *} \mathrm{p}<0.05,{ }^{* * *} \mathrm{p}<0.01$. Robust standard errors in parentheses are clustered at the year-of-birth level. 
Table 4: Impact of Social Security Income on Cognitive Function (IV)

\begin{tabular}{|c|c|c|c|c|c|}
\hline \multirow[b]{3}{*}{ Dep. var. } & (1) & $(2)$ & 3) & (4) & (5) \\
\hline & IV $1^{\text {st }}$ Stage & \multicolumn{4}{|c|}{ IV $2^{\text {nd }}$ Stage } \\
\hline & $\begin{array}{l}\text { Annual SS } \\
\text { income }^{\text {a }}\end{array}$ & Serial 7 & $\begin{array}{l}\text { Word } \\
\text { recall }\end{array}$ & $\begin{array}{c}\text { Mental } \\
\text { status }\end{array}$ & $\begin{array}{c}\text { Total } \\
\text { cognition } \\
\text { score } \\
\end{array}$ \\
\hline Annual SS income ${ }^{a}$ & & $\begin{array}{c}0.1546 * * * \\
(0.0312)\end{array}$ & $\begin{array}{l}0.5224 * * \\
(0.2156)\end{array}$ & $\begin{array}{c}0.2604^{* * *} \\
(0.0553)\end{array}$ & $\begin{array}{c}0.7827 * * * \\
(0.2319)\end{array}$ \\
\hline 1915-1917 cohort (IV) & $\begin{array}{c}0.7128 * * \\
(0.2774)\end{array}$ & & & & \\
\hline Primary beneficiary’s age & $\begin{array}{l}-0.0156 \\
(0.0226)\end{array}$ & $\begin{array}{c}-0.0158 * * \\
(0.0062)\end{array}$ & $\begin{array}{c}-0.0367 * * \\
(0.0175)\end{array}$ & $\begin{array}{c}-0.0410 * * * \\
(0.0105)\end{array}$ & $\begin{array}{c}-0.0777 * * * \\
(0.0248)\end{array}$ \\
\hline Male head - married & $\begin{array}{c}7.3930 * * * \\
(0.3311)\end{array}$ & $\begin{array}{l}-0.4299 \\
(0.2879)\end{array}$ & $\begin{array}{c}-3.0298 * * \\
(1.5239)\end{array}$ & $\begin{array}{l}-0.7852 \\
(0.4996)\end{array}$ & $\begin{array}{c}-3.8150 * * \\
(1.5811)\end{array}$ \\
\hline Male head - single & $\begin{array}{c}2.7570 * * * \\
(0.3376)\end{array}$ & $\begin{array}{c}0.1750 \\
(0.1783)\end{array}$ & $\begin{array}{l}-0.9939 \\
(0.6096)\end{array}$ & $\begin{array}{c}0.1448 \\
(0.3095)\end{array}$ & $\begin{array}{l}-0.8492 \\
(0.6545)\end{array}$ \\
\hline Female head - never married & $\begin{array}{c}1.0432 * * \\
(0.4824)\end{array}$ & $\begin{array}{c}0.5492 * * \\
(0.2619)\end{array}$ & $\begin{array}{l}-0.1031 \\
(0.5367)\end{array}$ & $\begin{array}{c}0.6110 \\
(0.4068)\end{array}$ & $\begin{array}{c}0.5079 \\
(0.8368)\end{array}$ \\
\hline Female head - widowed & $\begin{array}{c}1.0940 * * * \\
(0.1987)\end{array}$ & $\begin{array}{c}0.2505 \\
(0.1561)\end{array}$ & $\begin{array}{l}-0.4731 \\
(0.3768)\end{array}$ & $\begin{array}{c}0.2288 \\
(0.2452)\end{array}$ & $\begin{array}{l}-0.2442 \\
(0.5025)\end{array}$ \\
\hline MSA/Urban area & $\begin{array}{c}0.8560 * * * \\
(0.1616)\end{array}$ & $\begin{array}{c}0.0648 \\
(0.0620)\end{array}$ & $\begin{array}{l}-0.0065 \\
(0.2009)\end{array}$ & $\begin{array}{c}0.1003 \\
(0.0975)\end{array}$ & $\begin{array}{c}0.0938 \\
(0.2407)\end{array}$ \\
\hline Mid Atlantic & $\begin{array}{c}0.5958 \\
(0.6298)\end{array}$ & $\begin{array}{l}-0.0608 \\
(0.1114)\end{array}$ & $\begin{array}{l}-0.6663 \\
(0.4231)\end{array}$ & $\begin{array}{l}-0.0350 \\
(0.1709)\end{array}$ & $\begin{array}{l}-0.7013 \\
(0.5471)\end{array}$ \\
\hline EN Central & $\begin{array}{c}0.4984 \\
(0.4724)\end{array}$ & $\begin{array}{l}-0.0776 \\
(0.0968)\end{array}$ & $\begin{array}{l}-0.2801 \\
(0.3451)\end{array}$ & $\begin{array}{l}-0.0827 \\
(0.1359)\end{array}$ & $\begin{array}{l}-0.3629 \\
(0.4176)\end{array}$ \\
\hline WN Central & $\begin{array}{c}0.3533 \\
(0.5791)\end{array}$ & $\begin{array}{c}0.0890 \\
(0.0954)\end{array}$ & $\begin{array}{c}0.2630 \\
(0.4682)\end{array}$ & $\begin{array}{c}0.1810 \\
(0.1337)\end{array}$ & $\begin{array}{c}0.4440 \\
(0.5751)\end{array}$ \\
\hline S Atlantic & $\begin{array}{l}-0.4627 \\
(0.5995)\end{array}$ & $\begin{array}{l}-0.1178 \\
(0.1261)\end{array}$ & $\begin{array}{c}0.0420 \\
(0.4309)\end{array}$ & $\begin{array}{l}-0.2547 \\
(0.1834)\end{array}$ & $\begin{array}{l}-0.2127 \\
(0.5337)\end{array}$ \\
\hline ES Central & $\begin{array}{l}-0.0732 \\
(0.5537)\end{array}$ & $\begin{array}{c}-0.3690 * * \\
(0.1781)\end{array}$ & $\begin{array}{l}-0.2996 \\
(0.4465)\end{array}$ & $\begin{array}{l}-0.4341 \\
(0.2713)\end{array}$ & $\begin{array}{l}-0.7337 \\
(0.6602)\end{array}$ \\
\hline WS Central & $\begin{array}{l}-0.9428 * \\
(0.4793)\end{array}$ & $\begin{array}{l}-0.2098 * \\
(0.1110)\end{array}$ & $\begin{array}{l}-0.2306 \\
(0.4986)\end{array}$ & $\begin{array}{l}-0.4298 * \\
(0.2245)\end{array}$ & $\begin{array}{l}-0.6604 \\
(0.6521)\end{array}$ \\
\hline Mountain & $\begin{array}{l}-0.2357 \\
(0.5824)\end{array}$ & $\begin{array}{l}0.2347 * \\
(0.1209)\end{array}$ & $\begin{array}{c}1.2398 * * * \\
(0.4626)\end{array}$ & $\begin{array}{c}0.4611^{* *} \\
(0.1978)\end{array}$ & $\begin{array}{c}1.7009 * * * \\
(0.5514)\end{array}$ \\
\hline Pacific & $\begin{array}{c}0.1614 \\
(0.5598)\end{array}$ & $\begin{array}{c}0.1422 \\
(0.0966)\end{array}$ & $\begin{array}{c}0.4568 \\
(0.3521)\end{array}$ & $\begin{array}{c}0.4085 * * * \\
(0.1246)\end{array}$ & $\begin{array}{l}0.8654 * \\
(0.4519)\end{array}$ \\
\hline Primary beneficiary’s race - Hispanic & $\begin{array}{c}-3.0585^{* * *} \\
(0.3811)\end{array}$ & $\begin{array}{c}-0.7114 * * * \\
(0.1488)\end{array}$ & $\begin{array}{l}-0.0474 \\
(0.7081)\end{array}$ & $\begin{array}{c}-1.3953 * * * \\
(0.2757)\end{array}$ & $\begin{array}{l}-1.4427 * \\
(0.7745)\end{array}$ \\
\hline Primary beneficiary’s race - Black & $\begin{array}{c}-2.5791^{* * *} \\
(0.3795)\end{array}$ & $\begin{array}{c}-1.0622^{* * *} \\
(0.1483)\end{array}$ & $\begin{array}{l}-0.6929 \\
(0.6369)\end{array}$ & $\begin{array}{c}-2.0895 * * * \\
(0.2706)\end{array}$ & $\begin{array}{c}-2.7823 * * * \\
(0.7531)\end{array}$ \\
\hline Primary beneficiary’s race - Other & $\begin{array}{l}-1.2133 \\
(0.8014)\end{array}$ & $\begin{array}{l}-0.2777 \\
(0.2350)\end{array}$ & $\begin{array}{l}-0.3626 \\
(0.3809)\end{array}$ & $\begin{array}{l}-0.6985^{*} \\
(0.3843)\end{array}$ & $\begin{array}{l}-1.0611^{*} \\
(0.6098)\end{array}$ \\
\hline
\end{tabular}
-Continued- 
Table 4: Impact of Social Security Income on Cognitive Function (IV) (cont'd)

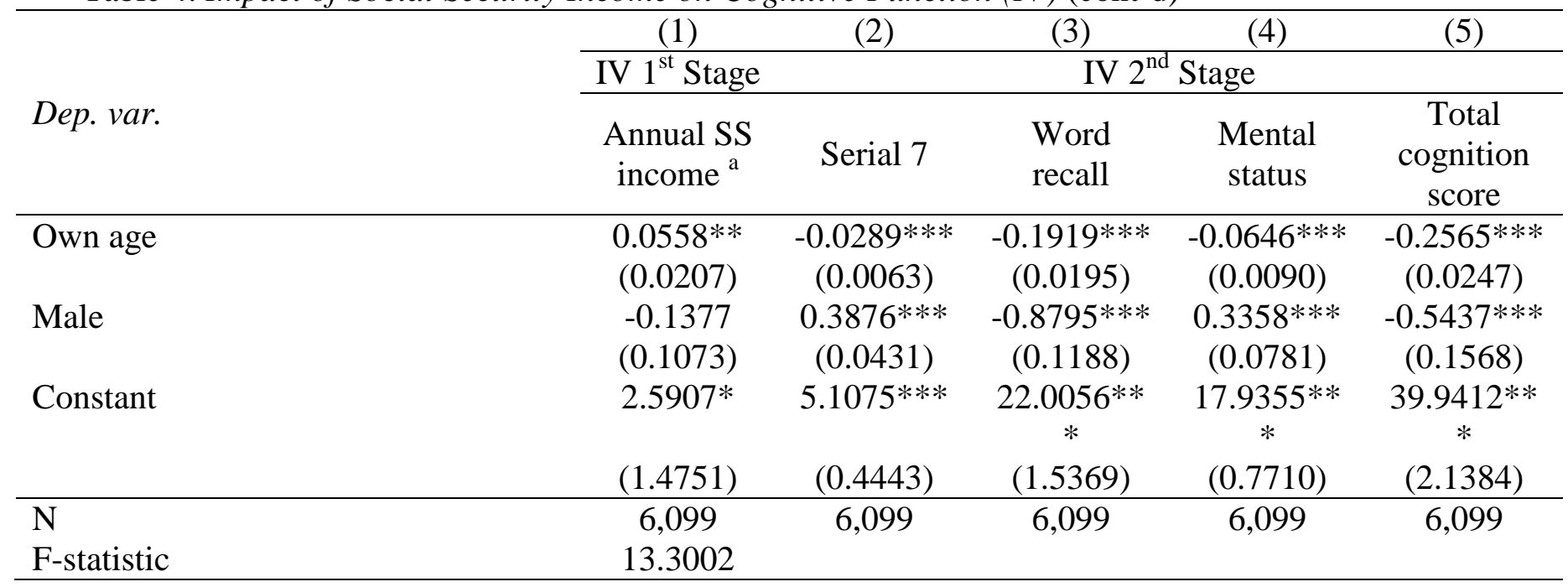

${ }^{a}$ in '000s 1993 USD.

Notes: ${ }^{*} \mathrm{p}<0.10,{ }^{* *} \mathrm{p}<0.05,{ }^{* * *} \mathrm{p}<0.01$. Robust standard errors in parentheses are clustered at the year-of-birth level. 
Table 5. Impact of Social Security Income on Physical and Mental Health (IV)

\begin{tabular}{|c|c|c|c|c|}
\hline \multirow[b]{2}{*}{ Dep. var. } & (1) & (2) & (3) & (4) \\
\hline & $\begin{array}{l}\text { Self-rated } \\
\text { health }\end{array}$ & ADL & IADL & CESD \\
\hline Annual SS income $^{a}$ & $\begin{array}{c}0.0508 \\
(0.0504)\end{array}$ & $\begin{array}{c}-0.0528^{* *} \\
(0.0266)\end{array}$ & $\begin{array}{c}-0.0615 * * * \\
(0.0219)\end{array}$ & $\begin{array}{l}-0.1484^{*} \\
(0.0883)\end{array}$ \\
\hline Primary beneficiary's age & $\begin{array}{c}0.0073 \\
(0.0048)\end{array}$ & $\begin{array}{c}0.0038 \\
(0.0047)\end{array}$ & $\begin{array}{c}0.0078 \\
(0.0050)\end{array}$ & $\begin{array}{c}0.0183^{* *} \\
(0.0075)\end{array}$ \\
\hline Male head - married & $\begin{array}{c}-0.5728 \\
(0.3637)\end{array}$ & $\begin{array}{c}0.2505 \\
(0.2068)\end{array}$ & $\begin{array}{c}0.5869 * * * \\
(0.1492)\end{array}$ & $\begin{array}{c}0.6123 \\
(0.6323)\end{array}$ \\
\hline Male head - single & $\begin{array}{c}-0.4794 * * * \\
(0.1555)\end{array}$ & $\begin{array}{c}0.0429 \\
(0.1107)\end{array}$ & $\begin{array}{l}0.1430 * \\
(0.0747)\end{array}$ & $\begin{array}{c}0.6062 * * \\
(0.2370)\end{array}$ \\
\hline Female head - never married & $\begin{array}{c}-0.2944 * * * \\
(0.1142)\end{array}$ & $\begin{array}{l}-0.1540 \\
(0.1121)\end{array}$ & $\begin{array}{c}0.1340 \\
(0.1142)\end{array}$ & $\begin{array}{l}-0.3854 \\
(0.2438)\end{array}$ \\
\hline Female head - widowed & $\begin{array}{c}-0.0827 \\
(0.0753)\end{array}$ & $\begin{array}{l}-0.0177 \\
(0.0700)\end{array}$ & $\begin{array}{c}0.1904^{* * *} \\
(0.0504)\end{array}$ & $\begin{array}{c}0.0788 \\
(0.1465)\end{array}$ \\
\hline MSA/Urban area & $\begin{array}{c}-0.1839 * * * \\
(0.0571)\end{array}$ & $\begin{array}{c}0.0266 \\
(0.0262)\end{array}$ & $\begin{array}{c}0.0419 \\
(0.0288)\end{array}$ & $\begin{array}{c}0.0875 \\
(0.0717)\end{array}$ \\
\hline Mid Atlantic & $\begin{array}{c}-0.0545 \\
(0.0997)\end{array}$ & $\begin{array}{c}0.0623 \\
(0.0545)\end{array}$ & $\begin{array}{c}0.0927 \\
(0.0608)\end{array}$ & $\begin{array}{c}0.0277 \\
(0.2116)\end{array}$ \\
\hline EN Central & $\begin{array}{c}-0.0529 \\
(0.0801)\end{array}$ & $\begin{array}{c}0.0578 \\
(0.0546)\end{array}$ & $\begin{array}{c}0.0796 \\
(0.0578)\end{array}$ & $\begin{array}{l}-0.1813 \\
(0.1948)\end{array}$ \\
\hline WN Central & $\begin{array}{c}-0.2015^{*} \\
(0.1043)\end{array}$ & $\begin{array}{c}0.0198 \\
(0.0617)\end{array}$ & $\begin{array}{c}0.0703 \\
(0.0514)\end{array}$ & $\begin{array}{c}-0.4900^{* *} \\
(0.1929)\end{array}$ \\
\hline S Atlantic & $\begin{array}{c}-0.0327 \\
(0.0870)\end{array}$ & $\begin{array}{c}0.0472 \\
(0.0390)\end{array}$ & $\begin{array}{c}0.0593 \\
(0.0579)\end{array}$ & $\begin{array}{c}-0.2874 \\
(0.1794)\end{array}$ \\
\hline ES Central & $\begin{array}{c}0.1804 \\
(0.1182)\end{array}$ & $\begin{array}{c}0.0146 \\
(0.0723)\end{array}$ & $\begin{array}{c}0.3255^{* * *} * \\
(0.1050)\end{array}$ & $\begin{array}{c}-0.1948 \\
(0.1944)\end{array}$ \\
\hline WS Central & $\begin{array}{l}0.1698^{*} \\
(0.0957)\end{array}$ & $\begin{array}{c}0.2049 * * * \\
(0.0577)\end{array}$ & $\begin{array}{c}0.1815^{* *} \\
(0.0762)\end{array}$ & $\begin{array}{c}0.1549 \\
(0.1717)\end{array}$ \\
\hline Mountain & $\begin{array}{c}-0.2868^{* *} \\
(0.1245)\end{array}$ & $\begin{array}{c}-0.0188 \\
(0.0495)\end{array}$ & $\begin{array}{l}-0.0077 \\
(0.0651)\end{array}$ & $\begin{array}{l}-0.3078 \\
(0.2279)\end{array}$ \\
\hline Pacific & $\begin{array}{c}-0.2134^{* * *} \\
(0.0807)\end{array}$ & $\begin{array}{c}0.0040 \\
(0.0475)\end{array}$ & $\begin{array}{c}0.0102 \\
(0.0547)\end{array}$ & $\begin{array}{c}-0.3815^{* *} \\
(0.1795)\end{array}$ \\
\hline Primary beneficiary’s race - Hispanic & $\begin{array}{c}0.6236^{* * *} \\
(0.1854)\end{array}$ & $\begin{array}{c}0.0248 \\
(0.1105)\end{array}$ & $\begin{array}{c}0.0904 \\
(0.0993)\end{array}$ & $\begin{array}{c}0.4662 \\
(0.3204)\end{array}$ \\
\hline Primary beneficiary’s race - Black & $\begin{array}{c}0.6136^{* * *} \\
(0.1631)\end{array}$ & $\begin{array}{l}-0.0059 \\
(0.0722)\end{array}$ & $\begin{array}{c}0.1727^{* *} \\
(0.0686)\end{array}$ & $\begin{array}{c}0.0261 \\
(0.2331)\end{array}$ \\
\hline Primary beneficiary's race - Other & $\begin{array}{c}0.4443^{* * *} \\
(0.1622)\end{array}$ & $\begin{array}{c}0.0362 \\
(0.1172)\end{array}$ & $\begin{array}{c}0.1077 \\
(0.0920)\end{array}$ & $\begin{array}{c}0.3175 \\
(0.2851)\end{array}$ \\
\hline Own age & $\begin{array}{c}0.0139 * * * \\
(0.0045)\end{array}$ & $\begin{array}{c}0.0181 * * * \\
(0.0034)\end{array}$ & $\begin{array}{c}0.0325^{* * *} \\
(0.0043)\end{array}$ & $\begin{array}{c}0.0172^{* *} \\
(0.0077)\end{array}$ \\
\hline Male & $0.0885 * * *$ & $\begin{array}{c}- \\
0.0731^{* * *} \\
(0.0191)\end{array}$ & $-0.0639 * *$ & $-0.3608 * * *$ \\
\hline
\end{tabular}

-Continued- 
Table 5. Impact of Social Security Income on Physical and Mental Health (IV) (cont’d)

\begin{tabular}{lcccc}
\hline \multirow{2}{*}{ Dep. var. } & $(1)$ & $(2)$ & $(3)$ & $(4)$ \\
\cline { 2 - 5 } & $\begin{array}{c}\text { Self-rated } \\
\text { health }\end{array}$ & ADL & IADL & CESD \\
\hline Constant & $1.3393^{* * *}$ & - & $-2.5299 * * *$ & 0.3313 \\
& $(0.2867)$ & $\begin{array}{c}0.9504^{* * *} \\
(0.2586)\end{array}$ & $(0.2496)$ & $(0.5997)$ \\
\hline
\end{tabular}

\section{First Stage Estimates}

\begin{tabular}{lcccc}
\hline Dep. var. & $\begin{array}{c}\text { Annual SS } \\
\text { income }^{\mathrm{a}}\end{array}$ & $\begin{array}{c}\text { Annual SS } \\
\text { income }^{\mathrm{a}}\end{array}$ & $\begin{array}{c}\text { Annual SS } \\
\text { income }^{\mathrm{a}}\end{array}$ & $\begin{array}{c}\text { Annual SS } \\
\text { income }^{\mathrm{a}}\end{array}$ \\
\hline 1915-1917 cohort (IV) & $\begin{array}{c}\text { (0.8605** } \\
(0.3298)\end{array}$ & $\begin{array}{c}0.8610^{* *} \\
(0.3298)\end{array}$ & $\begin{array}{c}0.8610^{* *} \\
(0.3298)\end{array}$ & $\begin{array}{c}0.7121^{* *} \\
(0.2775)\end{array}$ \\
& & & & \\
F-statistic & 18.9649 & 18.9889 & 18.9889 & 13.2758 \\
N & 6,627 & 6,632 & 6,632 & 6,098 \\
\hline
\end{tabular}

a in '000s 1993 USD.

Notes: ${ }^{*} \mathrm{p}<0.10,{ }^{* *} \mathrm{p}<0.05,{ }^{* * *} \mathrm{p}<0.01$. Robust standard errors in parentheses are clustered at the year-of-birth level. 
Table 6. Heterogeneous Effects by Educational Attainment - Cognitive Function

\begin{tabular}{|c|c|c|c|c|c|c|c|c|}
\hline & (1) & $(2)$ & (3) & (4) & (5) & (6) & (7) & (8) \\
\hline Sample: & $\begin{array}{l}<\text { High } \\
\text { school }\end{array}$ & $\begin{array}{l}\geq \text { High } \\
\text { school }\end{array}$ & $\begin{array}{l}<\text { High } \\
\text { school } \\
\end{array}$ & $\begin{array}{l}\geq \text { High } \\
\text { school }\end{array}$ & $\begin{array}{l}<\text { High } \\
\text { school } \\
\end{array}$ & $\begin{array}{l}\geq \text { High } \\
\text { school }\end{array}$ & $\begin{array}{l}<\text { High } \\
\text { school }\end{array}$ & $\begin{array}{l}\geq \text { High } \\
\text { school }\end{array}$ \\
\hline Dep. var. & Serial 7 & Serial 7 & $\begin{array}{l}\text { Word } \\
\text { recall }\end{array}$ & $\begin{array}{l}\text { Word } \\
\text { recall }\end{array}$ & $\begin{array}{l}\text { Mental } \\
\text { status }\end{array}$ & $\begin{array}{l}\text { Mental } \\
\text { status }\end{array}$ & $\begin{array}{c}\text { Total } \\
\text { cognition } \\
\text { score } \\
\end{array}$ & $\begin{array}{c}\text { Total } \\
\text { cognition } \\
\text { score } \\
\end{array}$ \\
\hline Annual SS income ${ }^{a}$ & $\begin{array}{l}0.1501^{*} \\
(0.0808)\end{array}$ & $\begin{array}{c}0.0769 \\
(0.1067)\end{array}$ & $\begin{array}{c}0.2521 \\
(0.1551)\end{array}$ & $\begin{array}{c}0.9070 \\
(0.8733)\end{array}$ & $\begin{array}{c}0.2114^{* *} \\
(0.1006)\end{array}$ & $\begin{array}{c}0.0849 \\
(0.1322)\end{array}$ & $\begin{array}{c}0.4635^{* *} \\
(0.2058)\end{array}$ & $\begin{array}{c}0.9919 \\
(0.8561)\end{array}$ \\
\hline $\begin{array}{l}1^{\text {st }} \text { stage coefficient } \\
1915-1917 \text { cohort (IV) }\end{array}$ & $\begin{array}{c}1.1405^{* * *} \\
(0.2647)\end{array}$ & $\begin{array}{c}0.3829 \\
(0.4256) \\
\end{array}$ & $\begin{array}{c}1.1405^{* * *} \\
(0.2647) \\
\end{array}$ & $\begin{array}{c}0.3829 \\
(0.4256) \\
\end{array}$ & $\begin{array}{c}1.1405^{* * *} \\
(0.2647)\end{array}$ & $\begin{array}{c}0.3829 \\
(0.4256) \\
\end{array}$ & $\begin{array}{c}1.1405^{* * *} \\
(0.2647) \\
\end{array}$ & $\begin{array}{c}0.3829 \\
(0.4256) \\
\end{array}$ \\
\hline $\begin{array}{l}\mathrm{N} \\
\text { F-statistic }\end{array}$ & $\begin{array}{c}2,450 \\
17.4719 \\
\end{array}$ & $\begin{array}{c}3,409 \\
1.8694 \\
\end{array}$ & $\begin{array}{c}2,450 \\
17.4719 \\
\end{array}$ & $\begin{array}{c}3,409 \\
1.8694 \\
\end{array}$ & $\begin{array}{c}2,450 \\
17.4719 \\
\end{array}$ & $\begin{array}{c}3,409 \\
1.8694 \\
\end{array}$ & $\begin{array}{c}2,450 \\
17.4719 \\
\end{array}$ & $\begin{array}{c}3,409 \\
1.8694 \\
\end{array}$ \\
\hline
\end{tabular}

${ }^{\mathrm{a}}$ in '000s 1993 USD

Notes: ${ }^{*} \mathrm{p}<0.10,{ }^{* *} \mathrm{p}<0.05,{ }^{* * *} \mathrm{p}<0.01$. Robust standard errors in parentheses are clustered at the year-of-birth level. 
Table 7. Heterogeneous Effects by Educational Attainment - Physical and Mental Health

\begin{tabular}{|c|c|c|c|c|c|c|c|c|}
\hline & (1) & (2) & (3) & (4) & (5) & (6) & (7) & (8) \\
\hline Sample: & $\begin{array}{l}<\text { High } \\
\text { school }\end{array}$ & $\begin{array}{l}\geq \text { High } \\
\text { school }\end{array}$ & $\begin{array}{l}<\text { High } \\
\text { school }\end{array}$ & $\begin{array}{l}\geq \text { High } \\
\text { school }\end{array}$ & $\begin{array}{l}<\text { High } \\
\text { school }\end{array}$ & $\begin{array}{l}\geq \text { High } \\
\text { school }\end{array}$ & $\begin{array}{l}<\text { High } \\
\text { school }\end{array}$ & $\begin{array}{l}\geq \text { High } \\
\text { school }\end{array}$ \\
\hline Dep. var. & $\begin{array}{l}\text { Self-rated } \\
\text { health }\end{array}$ & $\begin{array}{l}\text { Self-rated } \\
\text { health }\end{array}$ & ADL & ADL & IADL & IADL & CESD & CESD \\
\hline Annual SS income $^{a}$ & $\begin{array}{c}0.0415 \\
(0.0529)\end{array}$ & $\begin{array}{c}0.1325 \\
(0.1762)\end{array}$ & $\begin{array}{l}-0.0296 \\
(0.0219)\end{array}$ & $\begin{array}{c}-0.0744 \\
(0.0743)\end{array}$ & $\begin{array}{c}-0.0392 \\
(0.0252)\end{array}$ & $\begin{array}{c}-0.0302 \\
(0.0335)\end{array}$ & $\begin{array}{c}-0.2740 * * * \\
(0.0639)\end{array}$ & $\begin{array}{c}0.0575 \\
(0.1336)\end{array}$ \\
\hline $\begin{array}{l}1^{\text {st }} \text { stage coefficient } \\
1915-1917 \text { cohort (IV) }\end{array}$ & $\begin{array}{c}1.2265^{* * *} \\
(0.2433)\end{array}$ & $\begin{array}{c}0.5528 \\
(0.4957)\end{array}$ & $\begin{array}{c}1.2265 * * * \\
(0.2433)\end{array}$ & $\begin{array}{c}0.5534 \\
(0.4956)\end{array}$ & $\begin{array}{c}1.2265^{* * *} \\
(0.2433)\end{array}$ & $\begin{array}{c}0.5534 \\
(0.4956)\end{array}$ & $\begin{array}{c}1.1391 * * * \\
(0.2651)\end{array}$ & $\begin{array}{c}0.3829 \\
(0.4256)\end{array}$ \\
\hline $\begin{array}{l}\mathrm{N} \\
\text { F-statistic }\end{array}$ & $\begin{array}{c}2,739 \\
21.0498\end{array}$ & $\begin{array}{c}3,626 \\
3.7707\end{array}$ & $\begin{array}{c}2,739 \\
21.0498 \\
\end{array}$ & $\begin{array}{c}3,629 \\
3.7792\end{array}$ & $\begin{array}{c}2,739 \\
21.0498\end{array}$ & $\begin{array}{c}3,629 \\
3.7792 \\
\end{array}$ & $\begin{array}{c}2,449 \\
17.4302\end{array}$ & $\begin{array}{c}3,409 \\
1.8694\end{array}$ \\
\hline
\end{tabular}

a in '000s 1993 USD

Notes: ${ }^{*} \mathrm{p}<0.10,{ }^{* *} \mathrm{p}<0.05,{ }^{* * *} \mathrm{p}<0.01$. Robust standard errors in parentheses are clustered at the year-of-birth level. 
Table 8. Heterogeneous Effects on Total Cognition (IV Quantile Regressions)

\begin{tabular}{lccccc}
\hline & $(1)$ & $(2)$ & $(3)$ & $(4)$ & $(5)$ \\
\cline { 2 - 6 } & 10th quantile & 25th quantile & 50th quantile & 75th quantile & 90th quantile \\
\hline Annual SS income $^{\mathrm{a}}$ & $0.5503^{*}$ & $0.4433^{*}$ & $0.8637^{* * *}$ & $2.0448^{* * *}$ & $6.6554^{* * *}$ \\
& $(0.3040)$ & $(0.2368)$ & $(0.2443)$ & $(0.4287)$ & $(1.6777)$ \\
\hline Mean cognition & 9.1644 & 14.7448 & 18.5891 & 22.0190 & 24.8610 \\
$\mathrm{~N}$ & 6,099 & 6,099 & 6,099 & 6,099 & 6,099 \\
\hline
\end{tabular}

${ }^{\mathrm{a}}$ in '000s 1993 USD.

Notes: ${ }^{*} \mathrm{p}<0.10,{ }^{* *} \mathrm{p}<0.05,{ }^{* * *} \mathrm{p}<0.01$. Robust standard errors in parentheses are clustered at the year-of-birth level. 


\section{RECENT WORKING PAPERS FROM THE CENTER FOR RETIREMENT RESEARCH AT BOSTON COLLEGE}

Does Age-Related Decline in Ability Correspond with Retirement Age? Anek Belbase, Geoffrey T. Sanzenbacher, and Christopher M. Gillis, September 2015

Job Polarization and Labor Market Outcomes for Older, Middle-Skilled Workers Matthew S. Rutledge and Qi Guan, September 2015

What Causes Workers to Retire Before They Plan?

Alicia H. Munnell, Geoffrey T. Sanzenbacher, and Matthew S. Rutledge, September 2015

Calculating Neutral Increases in Retirement Age by Socioeconomic Status

Geoffrey T. Sanzenbacher, Anthony Webb, Candace M. Cosgrove, and Natalia S. Orlova, August 2015

How Does Occupational Access for Older Workers Differ by Education?

Matthew S. Rutledge, Steven A. Sass, and Jorge D. Ramos-Mercado, August 2015

How Much Longer Do People Need to Work?

Alicia H. Munnell, Anthony Webb, and Anqi Chen, August 2015

The Challenge of Pension Reform in Georgia: Non-Contributory Pensions and Elderly Poverty

Tamila Nutsubidze and Khatuna Nutsubidze, July 2015

The Transition from Defined Benefit to Defined Contribution Pensions: Does It Influence Elderly Poverty?

Natalia S. Orlova, Matthew S. Rutledge, and April Yanyuan Wu, July 2015

Will the Average Retirement Age Continue to Increase?

Matthew S. Rutledge, Christopher M. Gillis, and Anthony Webb, July 2015

The Role of Occupations in Differentiating Health Trajectories in Later Life

Michal Engelman and Heide Jackson, University of Wisconsin-Madison, July 2015

The Relationship Between Automatic Enrollment and DC Plan Contributions: Evidence from a National Survey of Older Workers

Barbara A. Butrica and Nadia S. Karamcheva, July 2015

Evidence of Increasing Differential Mortality: A Comparison of the HRS and SIPP Barry P. Bosworth and Kan Zhang, July 2015

All working papers are available on the Center for Retirement Research website (http://crr.bc.edu) and can be requested by e-mail (crr@bc.edu) or phone (617-552-1762). 